\title{
Diet of Boana albopunctata (Anura: Hylidae) in an Atlantic Forest fragment of southeastern Brazil
}

\author{
Eduardo Oliveira Pacheco, ${ }^{1,2}$ Vanessa Gonçalves Ferreira, ${ }^{1,2}$ and Rose Marie Hoffmann de \\ Carvalho $^{2}$ \\ ${ }^{1}$ Programa de Pós-Graduação em Biologia Animal, Centro de Ciências Biológicas e da Saúde, Universidade Federal de Mato \\ Grosso do Sul, 79070-900, Campo Grande, MS, Brazil. E-mail: eduardopachecosd@gmail.com. \\ ${ }^{2}$ Departamento de Zoologia, Instituto de Ciências Biológicas, Universidade Federal de Juiz de Fora, 36036-900, Juiz de Fora, \\ MG, Brazil. E-mail: rosemarie.hoffmann@ufjf.edu.br.
}

\begin{abstract}
Diet of Boana albopunctata (Anura: Hylidae) in an Atlantic Forest fragment of southeastern Brazil. Anurans are important in trophic food chains because they feed on invertebrates, many of which are harmful to humans. We investigated the diet of 100 specimens of Boana albopunctata from an Atlantic Forest fragment in Ponte Nova municipality, Minas Gerais state. We obtained 107 prey items. The most common prey were Lepidoptera, Araneae and Coleoptera. This species tended to select larger prey in smaller quantities as found in previous reports, but differed in the taxons selected because of spatial and temporal variation in microhabitats and the availability of invertebrates in savannas.
\end{abstract}

Keywords: food items, natural history, trophic ecology.

\begin{abstract}
Resumo
Dieta de Boana albopunctata (Anura: Hylidae) em um fragmento de Mata Atlântica do sudeste do Brasil. Anuros são importantes na cadeia trófica por se alimentarem de invertebrados, muitos dos quais são prejudiciais aos humanos. Nós investigamos a dieta de 100 espécimes de Boana albopunctata provenientes do município de Ponte Nova, Estado de Minas Gerais, em um fragmento da Mata Atlântica e obtivemos 107 presas, sendo as mais representativas Lepidoptera, Araneae e Coleoptera. A espécie tendeu a selecionar maiores presas em menores quantidades, assim como registrado em outros trabalhos, mas diferiu em táxons encontrados, devido à variação espacial e temporal de micro habitats das paisagens de Cerrado.
\end{abstract}

Palavras-chave: ecologia trófica, história natural, itens alimentares.

Received 27 November 2016 


\section{Introduction}

Anuran diets are determined by evolutionary, environmental and ecological factors that influence the selection of prey type and body shape, biomechanical structures for feeding, foraging strategies, body size and physiological restrictions (Wells 2007). Invertebrates compose the majority of anuran diets, but because of the opportunistic behavior of many species, anurans usually are considered to be generalist predators (Duellman and Trueb 1994, Wells 2007, Solé et al. 2009). However, prey items such as vertebrates are utilized by some species (Caldwell 1996, Rödel and Braun 1999, Hirai and Matsui 2000).

The Atlantic Forest in Brazil, a diverse biome, has the greatest number of endemic species of anurans in the world (Haddad et al. 2013). Research on anuran reproduction, distribution, and vocalization of its anurofauna is abundant (e.g., Bertoluci and Rodrigues 2002, Haddad and Prado 2005), but few studies on diets exist.

Boana albopunctata (Spix, 1824) (Figure 1) is an arboreal species broadly distributed in South America, occurring throughout northeastern Argentina, northern Uruguay, eastern Bolivia and eastern Paraguay (Frost 2016). The species is abundant throughout its range and in Brazil it occurs mainly in the central, southeast and northeast (Bahia state) regions (Haddad et al. 2013). Considered a habitat generalist, it occurs in open vegetation and does not depend on forest environments to breed (Brandão and Araújo 2001, Frost 2016).

Reports on the natural history and diet of $B$. albopunctata within its range are scarce, with only two studies conducted in the Cerrado in west-central Brazil (see Araújo et al. 2007, Guimarães et al. 2011). Herein, we describe the diet of B. albopunctata from an Atlantic Rainforest fragment in southeast Brazil. Our goal is to identify the food items that compose the diet and to provide information on the natural history of this species.

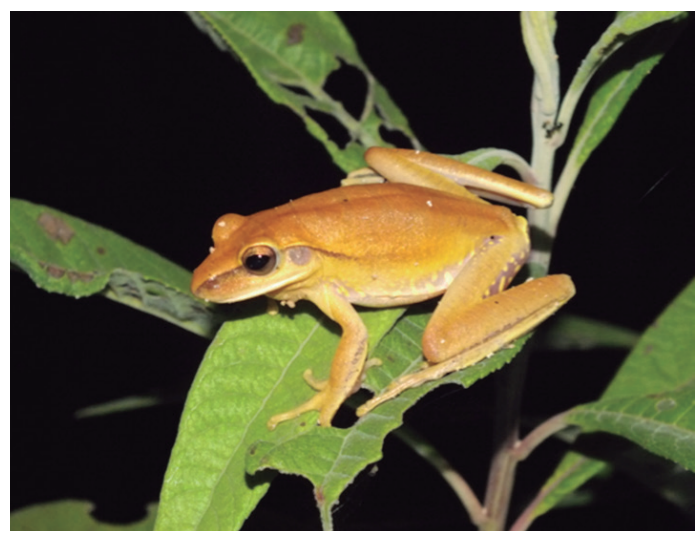

Figure 1. An adult Boana albopunctata, in an open area of Atlantic Forest in Fazenda Apaga Fogo, Ponte Nova municipality, Minas Gerais state, southeastern Brazil. Photo by Eduardo Pacheco.

\section{Materials and Methods}

We analyzed the stomach contents of 100 adult individuals (96 males and 4 non-gravid females) of Boana albopunctata (mean SLV = $48.2 \pm 4.5 \mathrm{~mm}$ ) from the herpetological collection of the Universidade Federal de Juiz de Fora, Minas Gerais state. The collection catalog indicates that the specimens were from Fazenda Apaga Fogo, Ponte Nova municipality, Minas Gerais state, southeastern Brazil. This area includes significant vegetation remnants of Atlantic Forest. The area is situated $431 \mathrm{~m}$ a.s.l. and has a humid subtropical climate (CWA), with a dry winter and a hot, humid summer (Peel et al. 2007). The mean annual temperature is around $19^{\circ} \mathrm{C}$. The specimens were collected during the rainy season (February 2014).

Stomachs were removed through a small abdominal incision and contents were placed in separate vials. Prey items were identified and preserved in $70 \%$ alcohol. We used a stereoscope microscope to identify the prey and to classify the items that we found according to their taxonomical order. We measured snout-vent length (SVL) and jaw width (JW) of each specimen using a digital caliper (to the nearest 
$0.01 \mathrm{~mm})$. We measured prey length and width and estimated prey volume from an ellipsoid formula (Griffiths and Mylotte 1987): $\mathrm{V}=$ $(4 \pi / 3)(w / 2)^{2}(l / 2)$, where $w$ is the width of each prey, and $l$ is the length of each prey. Stomach contents (CAUFJF 1233-1289, 1300-1344) were deposited in the herpetological collection at the Universidade Federal de Juiz de Fora.

For each anuran specimen and for the total of examined stomachs, we calculated the numerical and volumetric percentages of each prey category. We calculated the Index of Relative Importance (IRI) to determine the importance of each prey category in the diet of B. albopunctata by using the equation of Pinkas et al. (1991): IRI $=F \%(N \%+V \%)$, where $F \%$ is the mean percentage of prey occurrence, $N \%$ is the numerical percentage of prey and $V \%$ is the volumetric percentage of prey.

We utilized a simple linear regression to associate body size (SVL) with the largest prey volume found in each stomach (e.g., Sabagh and Carvalho-e-Silva 2008). We performed a simple linear regression with $\mathrm{R}$ program to evaluate the relationship between JW and the prey dimensions. The data showed normality required for linear regressions.

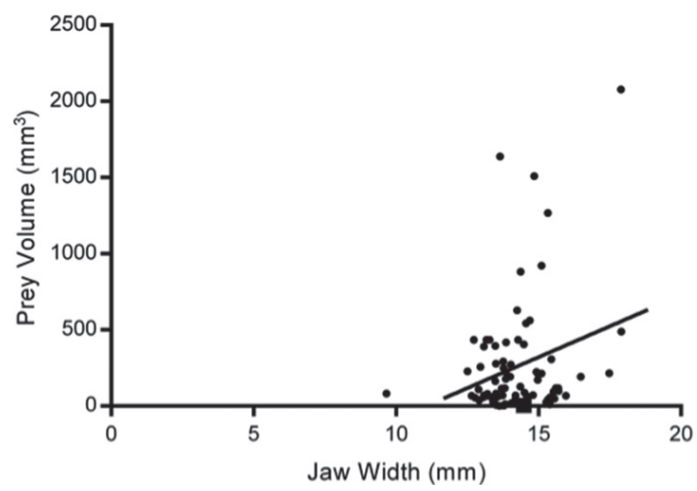

Figure 2. The relationship between jaw width (JW) and and the prey item with the largest volume in each stomach of Boana albopunctata.

\section{Results}

Among the analyzed stomachs, 30 (30\%) were empty and the other 70 stomachs (70\%) contained at least one prey item. We obtained 107 prey items (Table 1), representing 7 insect orders, including Coleoptera, Hemiptera, Hymenoptera, larval Lepidoptera, Mantodea, Odonata and Orthoptera. We also observed Acari, Araneae and Gastropoda. The most frequent items were Lepidoptera (21.05\%), Araneae (17.89\%) and Coleoptera (15.79\%). According to the IRI, these items were the most important in the diet of Boana albopunctata. Regarding prey volume, Orthoptera (34.36\%), Lepidoptera (larvae) (20.44\%) and Araneae $(14.38 \%)$ were the most common items. However, $14.74 \%$ of prey were largely digested, making it impossible to identify them.

Jaw width and SVL of B. albopunctata were correlated with prey volume $\left(\mathrm{r}^{2}=0.0721, p=\right.$ $0.0175 ; \mathrm{r}^{2}=0.0881, p=0.0083$; Figures 2 and 3 ), indicating that individuals with larger jaws and body size fed on larger prey. We did not observe a significant association between SVL and the total number of prey in the stomach $(p=$ $0.493)$.

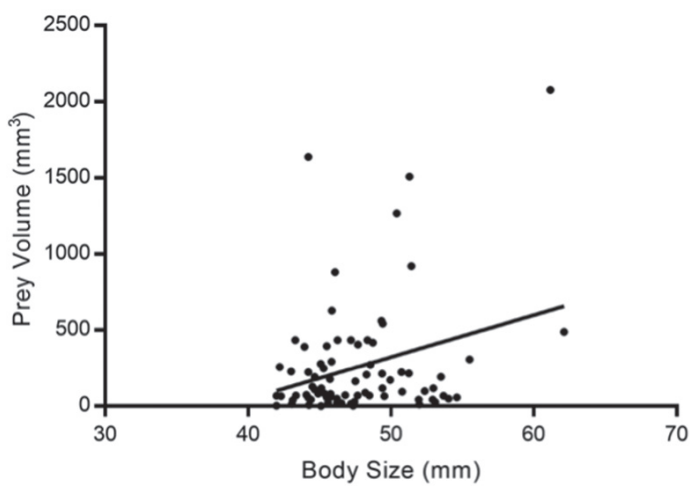

Figure 3. The relationship between body size (SLV) and prey item with the largest volume in each stomach of Boana albopunctata. 
Table 1. Diet of Boana albopunctata in the Atlantic Forest fragment in southeast Brazil with their respective volume $(\mathrm{V}$ and $\mathrm{V} \%$ ) absolute values and relative abundance ( $\mathrm{N}$ and $\mathrm{N} \%$ ) frequency ( $\mathrm{F}$ and $\mathrm{F} \%$ ) and importance value index (IRI).

\begin{tabular}{lccccccc}
\hline Category & $\mathbf{V}\left(\mathbf{m m}^{\mathbf{3}}\right)$ & $\mathbf{V} \%$ & $\mathbf{N}$ & $\mathbf{N} \%$ & $\mathbf{F}$ & $\mathbf{F} \%$ & $\mathbf{I R I}$ \\
\hline $\begin{array}{l}\text { ARTHROPODA } \\
\text { Arachnida } \\
\quad \text { Acari }\end{array}$ & 0.50 & $<0.01$ & 4 & 3.74 & 2 & 2.11 & 7.87 \\
$\quad$ Araneae & & & & & & & \\
Insecta & 3589.24 & 14.38 & 20 & 18.69 & 17 & 17.89 & 591.88 \\
$\quad$ Coleoptera & & & & & & & \\
Hemiptera & 3460.00 & 13.87 & 17 & 15.89 & 15 & 15.79 & 469.79 \\
Hymenoptera & 2528.65 & 10.13 & 9 & 8.41 & 9 & 9.47 & 175.68 \\
$\quad$ Lepidoptera (larvae) & 131.60 & 0.53 & 7 & 6.54 & 6 & 6.32 & 44.64 \\
$\quad$ Mantodea & 5100.15 & 20.44 & 24 & 22.43 & 20 & 21.05 & 902.50 \\
$\quad$ Odonata & 322.80 & 1.29 & 2 & 1.87 & 2 & 2.11 & 6.65 \\
$\quad$ Orthoptera & 3.23 & 0.01 & 1 & 0.93 & 1 & 1.05 & 0.99 \\
MOLLUSCA & 8574.37 & 34.36 & 8 & 7.48 & 8 & 8.42 & 352.32 \\
$\quad$ Gastropoda & & & & & & & \\
UNDETERMINED & 7.21 & 0.03 & 1 & 0.93 & 1 & 1.05 & 1.01 \\
\hline
\end{tabular}

\section{Discussion}

Previous studies have indicated that species of Hylidae are generalists (Brandão and Araújo 2001). Boana albopunctata consumed a wide variety of food items, explaining the feeding strategy and reflecting the availability of these prey in the environment. The larval stages of Lepidoptera, Araneae and Coleoptera were the most frequent items in its diet.

Consumption of larval Lepidoptera can be related to energetic gain for $B$. albopunctata. Larval insects have low mobility, few structures lined with exoskeletons (Batista et al. 2011) and, hence, more digestible material than other prey categories. Lepidoptera larvae become an attractive prey because the frog exspends little energy to capture an energetically profitable prey. Araneae was the second most common and numerically consumed prey. Numerous groups of spiders weave their webs among shrubs near streams (Rodrigues and Mendonça Jr. 2012, Rodrigues et al. 2014), making them susceptible to predation by species that use shrubs as a microhabitat. Coleoptera, the third most important item in the diet of B. albopunctata, is frequently reported as most abundant item in studies of anuran diets (e.g., Duré and Kehr 2004, Maneyro et al. 2004, Schaefer et al. 2006, Pazinato et al. 2011). This order is predictably the most available in the environment because of its high diversity, being the taxon with more species (Rafael et al. 2012) and its high abundance in hot climates. The empty stomachs found in the current study can indicate investment in vocalization because males do not eat during reproductive periods (Van Sluys and Rocha 1998), or it may be because of the time between capture and fixation of specimens.

Araújo et al. (2007) assessed the diet of Boana albopunctata in a population from the Cerrado in the rainy season and found that 
Hymenoptera and Lepidoptera were the most numerically abundant categories. Another Cerrado population of $B$. albopunctata was sampled in rainy and dry seasons, and Coleoptera, Aranae and Orthoptera were the most important items for that population (Guimarães et al. 2011). The difference between diet composition of the Cerrado population and the Atlantic Forest population may be due the habitat and prey availability differences between the two regions, since the previous studies were conducted in the rainy season. Like Araújo et al. (2007) and Guimarães et al. (2011), we observed a tendency for frogs to select larger prey in smaller quantities, such as Orthoptera and Lepidoptera. Individuals of $B$. albopunctata in the Atlantic Forest seem to pursue a strategy of low energetic cost in foraging.

Prey selection among different orders is influenced by prey size, mobility, palatability, nutritional value, availability and abundance in the environment (Santos et al. 2003). Another important aspect related to prey selection is the anuran head size, which is a determinant in choosing the maximum size of prey that can be consumed (Duellman and Trueb 1994). Our results indicate that the relationship between body size (SVL) and jaw width (JW) is significant. Guimarães et al. (2011) also found a positive relationship between prey and anuran head measurements. Body size or gape size is an important factor in choosing a suitable prey size (Strüssmann et al. 1984), ensuring the ingestion of various types and proportions of prey based on the ability to open the mouth (Pough et al. 2004). This pattern is known in amphibians of the families Bufonidae, Leptodactylidae and Cycloramphidae (Duellman and Trueb 1994) and, once larger individuals select larger prey, intraspecific competition is prevented (Guimarães et al. 2011).

Based on our results we conclude that Boana albopunctata from an Atlantic Forest fragment in southeast of Brazil is a generalist food and habitat species, as indicated in previous reports (Brandão and Araújo 2001). Nevertheless, our results are biased because the specimens used for this work were taken from a herpetological collection, and we do not have information on the time elapsed between capture and fixation of the specimens. Despite this bias, we found a large number of food items, reinforcing the idea that B. albopunctata is a predator with opportunistic behavior, similar to another population in the Brazilian Cerrado. Therefore, this work contributes to the natural history of this species and emphasizes the importance of conducting studies in different habitats to understand feeding patterns of widely distributed species.

\section{Acknowledgments}

We are grateful to animal use ethic committee of the Universidade Federal de Juiz de Fora by the approval the procedures with specimens and to the herpetological collection from Universidade Federal de Juiz de Fora by borrowing the specimens for this study. We thank Janalee Caldwell for English review. We also thank F. M. Lanna, E. M. Fonseca, M. O. Neves and L. Nascimento for the support in this study and two anonymous reviewers for the helpful comments in manuscript. EOP and VGF thank Universidade Federal de Juiz de Fora and CAPES for their scholarships.

\section{References}

Araújo, F. R. R. C., A. Bocchiglieri, and R. M. Holmes. 2007. Ecological aspects of the Hypsiboas albopunctatus (Anura, Hylidae) in Central Brazil. Neotropical Biology and Conservation 2: 165-169.

Bertoluci, J. and M. T. Rodrigues. 2002. Utilização de habitats reprodutivos e micro-habitats de vocalização em uma taxocenose de anuros (Amphibia) de Mata Atlântica do sudeste do Brasil. Papéis Avulsos de Zoologia 42: 287-297.

Brandão, R. A. and A. F. B. Araújo. 2001. A herpetofauna associada às matas de galeria no Distrito Federal. Pp. 561-604 in J. F. Ribeiro, C. E. L. Fonseca, and J. C. Sousa-Silva (eds.), Cerrado: Caracterização e Recuperação de Matas de Galeria. Planaltina. Embrapa Cerrados. 
Caldwell, J. P. 1996. The evolution of myrmecophagy and its correlates in poison frogs (Family Dendrobatidae). Journal of Zoology 240: 75-101.

Batista, R. C., C. B. De-Carvalho, E. B. Freitas, S. C. Franco, C. C. Batista, W. A. Coelho, and R. G. Faria. 2011. Diet of Rhinella schneideri (Werner, 1894) (Anura: Bufonidae) in the Cerrado, central Brazil. Herpetology Notes 4: 17-21.

Duellman, W. E. and L. Trueb. 1994. Biology of Amphibians. Baltimore and London. The John Hopkins University Press. $610 \mathrm{pp}$.

Duré, M. I. and A. I. Kehr. 2004. Influence of microhabitat on the trophic ecology of two leptodactylids from northeastern Argentina. Herpetologica 60: 295-303.

Frost D. R. (ed). 2016. Amphibian Species of the World: an Online Reference. Version 6.0. (January 2014). Electronic Database accessible at http://research.amnh. org/herpetology/amphibia/American Museum of Natural History, New York, USA. Captured on 23 June 2016.

Griffiths, R. A. and V. J. Mylotte. 1987. Microhabitat selection and feeding relations of smooth and warty newts, Triturus vulgaris and T. cristatus, at an upland pond in mid-Wales. Ecography 10: 1-7.

Guimarães, T. C. S., G. B. Figueiredo, D. O. Mesquita, and M. M. Vasconcellos. 2011. Ecology of Hypsiboas albopunctatus (Anura: Hylidae) in a neotropical savanna. Journal of Herpetology 45: 244-250.

Haddad, C. F. B. and C. P. A. Prado. 2005. Reproductive modes in frogs and their unexpected diversity in the Atlantic Forest of Brazil. BioScience 55: 207-217.

Haddad, C. F. B., L. F. Toledo, C. P. A. Prado, D. Loebmann, J. L. Gasparini, and I. Sazima (eds.). 2013. Guia dos Anfíbios da Mata Atlântica: Diversidade e Biologia. São Paulo. Anolis Books. 544 pp.

Hirai, T. and M. Matsui. 2000. Ant specialization in diet of the narrow-mouthed toad, Microhyla ornata, from Amamioshima Island of the Ryukyu Archipelago. Current Herpetology 19: 27-34.

Maneyro, R., D. E. Naya, I. Rosa, A. Canavero, and A. Camargo. 2004. Diet of the South American frog Leptodactylus ocellatus (Anura: Leptodactylidae) in Uruguay. Iheringia, Série Zoologia 94: 57-61.

Pazinato, D. M. M., A. O. Trindade, S. V. Oliveira, and L. H. Capellari. 2011. Dieta de Leptodactylus latrans (Steffen, 1815) na Serra do Sudeste, Rio Grande do Sul, Brasil. Biotemas 24: 147-151.

Peel, M. C., B. L. Finlayson, and T. A. McMahon. 2007. Updated world map of the Köppen-Geiger climate classification. Hydrology and Earth System Science 11: $1633-1644$.
Pough, F. H., R. M. Andrews, J. E. Cadle, M. L. Crumps, A. H. Savitzky, K. D. Wells, and M. C. Brandley. 2004. Herpetology. New Jersey. Upper Saddle River. 736 pp.

Rafael, J. A., G. A. R. Melo, C. J. B. Carvalho, S. A. Casari, and R. Constantino (eds.). 2012. Insetos do Brasil: Diversidade e Taxonomia. Ribeirão Preto. Holos Editora. 810 pp.

Rödel, M. O. and U. Braun. 1999. Associations between anurans and ants in a West African savanna (Anura: Microhylidae, Hyperoliidae, and Hymenoptera: Formicidae). Biotropica 31: 178-183.

Rodrigues, E. N. L. and M. S. Mendonça Jr. 2012. Spider guilds in the tree-shrub strata of riparian forests in southern Brazil. Journal of Arachnology 40: 39-47.

Rodrigues, E. N. L., M. S. Mendonça Jr, and L. E. CostaSchmidt. 2014. Spider diversity responds strongly to edge effects but weakly to vegetation structure in riparian forests of Southern Brazil. Arthropod-Plant Interactions 8: 123-133.

Sabagh, L. T. and A. M. P. T. Carvalho-e-Silva. 2008. Feeding overlap in two sympatric species of Rhinella (Anura: Bufonidae) of the Atlantic Rain Forest. Revista Brasileira de Zoologia 25: 247-253.

Santos, J. W. A., R. P. Damasceno, and P. L. B. Rocha. 2003. Feeding habits of the frog Pleurodema diplolistris (Anura, Leptodactylidae) in Quaternary sand dunes of the middle Rio São Francisco, Bahia, Brazil. Phyllomedusa 2: 83-92.

Schaefer, E. F., M. I. Hamann, A. I. Kehr, C. E. González, and M. I. Duré. 2006. Trophic, reproductive and parasitological aspects of the ecology of Leptodactylus chaquensis (Anura: Leptodactylidae) in Argentina. Herpetological Journal 16: 387-394.

Solé, M., I. R. Dias, E. A. S. Rodrigues, E. Marciano-Jr., S. M. J. Branco, K. P. Cavalcante, and D. Rödder. 2009. Diet of Leptodactylus ocellatus (Anura: Leptodactylidae) from a cacao plantation in southern Bahia, Brazil. Herpetology Notes 2: 9-15.

Strüssmann, C., M. B. R. Vale, M. H. Meneguini, and W. E. Magnusson. 1984. Diet and foraging mode of Bufo marinus and Leptodactylus ocellatus. Journal of Herpetology 18: 138-146.

Van Sluys, M. and C. F. D. Rocha. 1998. Feeding habitats and microhabitat utilization by two syntopic Brazilian Amazonian frogs Hyla minuta and Pseudopaludicula sp. (gr. falcipes). Revista Brasileira de Biologia 58: 559562.

Wells, K. D. 2007. The Ecology and Behavior of Amphibians. Chicago. University Chicago Press. 1148 pp. 